
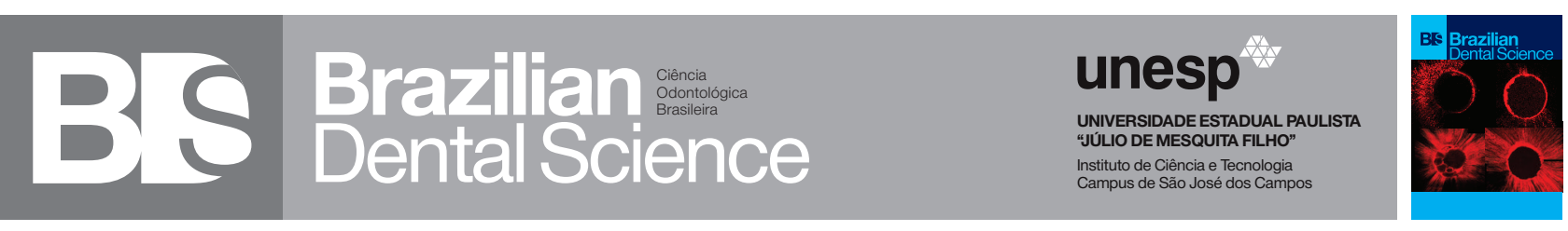

\title{
Concomitant using of topical carrageenan-kappa and oral vitamin $D$ against 7, 12-dimethylbenz[a]anthracene induced-oral cancer in rats: A synergism or an antagonism effects
}

Uso concomitante de carragenina tópica e vitamina D oral contra câncer de boca em ratos induzido por 7,12-dimetilbenz(a) antraceno: efeitos sinérgicos ou antagonistas

Aseel J. ALI' ${ }^{1}$, Jamal N. AHMED ${ }^{2}$, Marwan S.M. AL-NIMER ${ }^{3}$

1 - Al Ma'amon Dental Care Centre - Ministry of Health - Baghdad - Iraq.

2 - Department of Oral Medicine - College of Dentistry - Baghdad University - Baghdad - Iraq.

3 - Department of Pharmacology and Toxicology - College of Pharmacy - Hawler Medical University - Erbil - Iraq.

\section{ABSTRACT}

Objective: K-carrageenan is a food stabilizer agent which has an antiproliferative effect, while vitamin $\mathrm{D}$ is a prohormone acts on the nuclear receptor and has a cytotoxic against cancer. This study aimed to show the synergistic effect of using topical K-carrageenan and oral administration of the vitamin $\mathrm{D}$ on the 7, 12-dimethylbenz[a] anthracene (DMBA)-induced oral cancer. Material and Methods: fifty four male albino rats were randomly divided into seven groups: Acetonetreated served as control (Group I), vitamin D (5000UI)-treated (Group II), K-carrageenan (1\%)treated (Group III), DMBA (0.5\%)-treated (Group IV), Acetone, k-carrageenan and DMBA were administered topically on both cheeks and palate, five times weekly for 12 weeks, while the vitamin D was administered orally twice weekly for 12 weeks. Groups V, VI, and VII were animals treated with vitamin $\mathrm{D}$, $\mathrm{k}$-carrageenan, and both vitamin $\mathrm{D}$ and $\mathrm{K}$-carrageenan for 8 weeks after induction of oral cancer. At the end of the study, blood samples were obtained by cardiac puncture for determination of TNF- $\alpha$ and EGFR. Results: In the groups III and IV, serum EGFR showed significant low levels compared with Group I. In the Group VII, serum EGFR showed a significantly $(\mathrm{p}=0.014)$ low level compared with Group IV (614.3 \pm 69.7 $\mathrm{pg} / \mathrm{ml}$ versus $882.4 \pm 45.6 \mathrm{pg} / \mathrm{ml}$, respectively). Higher percentages of high levels of TNF- $\alpha$ were observed in the Groups VI and VII, while a lower percentage of EGFR was observed in the Group VI. Conclusion: both K-carrageenan and vitamin

\section{RESUMO}

Objetivo: K-carragenina é um agente estabilizador de alimentos que tem efeito um antiproliferativo, enquanto a vitamina $\mathrm{D}$ é um pró-hormônio que atua sobre o receptor nuclear e possui efeito citotóxico contra o câncer. Este estudo teve como objetivo mostrar o efeito sinérgico do uso de k-carragenina tópica e administração oral da vitamina D no câncer de boca induzido por 7 , 12-dimetilbenz[a]antraceno (DMBA). Material e Métodos: cinquenta e quatro ratos albinos machos foram divididos aleatoriamente em sete grupos: tratado com acetona como controle (Grupo I), tratado com vitamina D (5000UI) (grupo II), tratado com K-carragenina (1\%) (grupo III), DMBA $(0,5 \%)$ tratado (Grupo IV), acetona, K-carragenina e DMBA foram administrados topicamente nas bochechas e no palato, cinco vezes por semana durante 12 semanas, enquanto a vitamina $\mathrm{D}$ foi administrada por via oral duas vezes por semana durante 12 semanas. Os grupos V, VI e VII foram animais tratados com vitamina $\mathrm{D}$, K-carragenina e No final do estudo, foram obtidas amostras de sangue por punção cardíaca para determinação do TNF-a e EGFR. Resultados: Nos grupos III e IV, o EGFR sérico mostrou níveis baixos significativos em comparação com o Grupo I. No grupo VII, o EGFR sérico mostrou um nível significativamente baixo $(\mathrm{p}=0,014)$ em comparação com o Grupo IV $(614,3 \pm 69,7 \mathrm{pg} / \mathrm{ml}$ versus $882,4 \pm 45,6 \mathrm{pg} / \mathrm{ml}$, respectivamente). Maiores porcentagens de TNF- $\alpha$ foram observadas nos Grupos VI e VII, enquanto uma menor porcentagem de EGFR foi observada no 
D have antiproliferative effect against DMBAinducing oral cancer by increasing the levels of TNF- $\alpha$ and suppressing the signaling pathway of EGFR. Concomitant using K-carrageenan and vitamin $\mathrm{D}$ reduces the antiproliferative effect of each other.

\section{KEYWORDS}

Oral cancer; 7, 12-dimethylbenz[a] anthracene; Vitamin D; K-carrageenan; Epidermal growth factor receptor; Tumor necrosis factor- $\alpha$.
Grupo VI. Conclusão: Tanto a K-carragenina quanto a vitamina D têm efeito antiproliferativo contra o câncer de boca induzido por DMBA aumentando os níveis de TNF- $\alpha$ e suprimindo a via de sinalização do EGFR. O uso concomitante de K-carragenina e a vitamina $\mathrm{D}$ reduz o efeito antiproliferativo um do outro.

\section{PALAVRAS-CHAVE}

Câncer bucal; 7, 12-dimetilbenz [a] antraceno; Vitamina D; K-carragenina; Receptor do fator de crescimento epidérmico; Fator de necrose tumoral-a.

\section{INTRODUCTION}

7 ,12-dimethylbenz[a] anthracene (DMBA) is a carcinogenic chemical substance that used experimentally to induce a different variety of tumors in an attempt to study the pathogenesis of tumor and to assess the chemotherapeutic agents [1-3]. Experimentally, several studies showed the effectiveness of many substances in reducing or attenuating the effects of DMBA-induced tumorogenesis by improving the antioxidant status, augmenting the apoptosis, inducing antiproliferative, and activation of cytotoxic $\mathrm{T}$ cell-dependent tumor regression [4-7]. There are several biomarkers that contribute or related to the oral cancer. Tumor necrosis factor (TNF)- $\alpha$ is a proinflammatory cytokine that expressed in the oral cancer cells, and its level is used as a prognostic biomarker [8]. BALB/c mice exposed to oral administration of DMBA showed a significant high expression level of TNF- $\alpha$ [9] . Activation of epidermal growth factor receptor (EDFR) leads to activation of metabolic pathways that cause progression of the oral cancer, suggesting that EGFR plays a role in the development of the cancer stem cells [10]. In animal skin cancer model using DMBA, the activity of EGFR pathways are significantly increased compared with control animals [11].

K-carrageenan is a food stabilizer agent which used in different pharmaceutical formulation to prepare several compounds categorized as antioxidant, anti-inflammatory, antiinfective and antiproliferative [12-15]. Low molecular weight and sulfated cytotoxic substances derived from carrageenan showed anticancer property via inducing apoptosis and inhibiting the interactions between cell-to cell and cell-to matrix ground substances. Also, they can be used with anticancer agents to suppress the growth and the metastasis of the tumor [16]. Vitamin D is a prohormone acts on the nuclear receptor and has pleiotropic effects beyond its nutriceutical actions. Experimental studies carried on the cancer cell lines showed that vitamin $\mathrm{D}$ is cytotoxic against cancer cells by inducing apoptosis $[17,18]$. In human, the vitamin $\mathrm{D}$ reduces the risk of cancers and maintains high serum levels of vitamin D in cancer-patients which improve the survival rate [19]. The rational of the study is both $\mathrm{K}$-carrageenan and vitamin D have pleiotropic effects including anticancer through different mechanisms, and application of these substances via different routes can attenuate the oral cancer induced by DMBA. The aim of this study was to show the synergistic effect of using topical K-carrageenan and oral administration of the vitamin D on the DMBA-induced oral cancer using epidermal growth factor receptor (EGFR) and tumor necrosis factor- $\alpha$ (TNF- $\alpha$ ) as biomarkers.

\section{MATERIAL AND METHODS}

\section{Ethical Approval}

The Scientific Committee in the College of Dentistry at Baghdad University approved this 
experimental study. This study was registered (Code No. 6C/315 in March 2019) in the Department of postgraduate studies at the College of Dentistry. The principle of doing this study was to investigate the biomarkers that linked with carcinogenesis.

\section{Animals}

The National Center for Drug Control and Research (NCDCR), Ministry of Health in Baghdad supplied the animals and the Animal Care Department at the Biotechnology Research Center, The University of Al-Nahrin in Baghdad considered the animal housing and care. Male Wistar albino rats (weighing 150-175 g) were housed four per cage, under a standard laboratory control condition at room temperature of $25 \pm 2^{\circ} \mathrm{C}$ and humidity $(50 \pm 10 \%)$, 12-hour light/dark cycle, fed with a standard rat chow diet, and free access to tap water. After 1 week of acclimatization, the animals were divided into seven groups:

Group I ( $n=7)$ treated with an equal volume of acetone ( a solvent of DMBA) and served as the negative control.

Group II $(n=9)$ treated with oral dose (5000UI) vitamin D twice weekly

Group III $(n=7)$ : treated with topical application of K-carrageenan (1\%).

Group IV $(n=31)$ : treated with topical application of DMBA $(0.5 \% \mathrm{w} / \mathrm{v}$, dissolved in acetone).

The animals of Group I, II, and IV were treated topically (the chemicals applied to both check and palate using a brush size \#4 under light anesthesia), five times per week for 12 weeks. Then 21 rats of Group IV were subgrouped into:

Group V $(n=7)$ : treated with an oral dosage of vitamin D (5000UI) twice weekly via stainless feeding tube for 8 weeks.

Group VI $(n=7)$ : treated with topical application of K-carrageenan (1\%) for 8 weeks.

Group VII ( $n=7)$ : treated with simultaneous administration of an oral dosage of vitamin D (5000UI) twice weekly and topical application of K-carrageenan (1\%) five times weekly for 8 weeks.
Water and pellets access was not allowed for at least two hours to avoid the washing out of the chemicals. During the study, the animals were checked for the appearance of mass or ulcerative lesion, and the number, size, and the characteristic features of the lesion were recorded. Also, access to water and pellets by the animals and the number of dead animals during the study were recorded. At the end of the study, blood samples were obtained by cardiac puncture under light anesthesia, and the check bearing tumor lesion was excised for further histopathological study. Blood samples were centrifuged at 3,000 R.P.M. for 15 minutes, the sera separated and kept in the deep freeze at $-20^{\circ} \mathrm{C}$ for further determination of TNF- $\alpha$, and EGFR by Enzyme-Linked ImmunoSorbent Technology (ELISA) according to the instructions of the manufacturers.

\section{Statistical analysis}

The results are expressed as number, percentages, and mean \pm SEM of the number of animals. The difference between means was analysed using one way analysis of variances (ANOVA) with post hoc Boneferroni two-tailed independent two sample test. P-value at a level of $\leq 0.05$ considered significant. Statistical analyses and figure were performed by using Statistical Package for Social Sciences (SPSS-IBM, version 21) software for Windows.

\section{RESULTS}

Table I shows significant differences between treated groups (Group I, II, III, IV) in the means of the serum levels of EGFR ( $F=5.530$, $\mathrm{p}=0.004)$. Animals treated with $\mathrm{K}$-carrageenan (Group III) showed a significantly lower serum level of EGFR compared with the corresponding level of Group I, which account a $22.2 \%$ decrease. Group IV $(n=10)$ animals showed significantly lower serum EGFR levels compared with the corresponding value of Group I, which accounted for $21.1 \%$ (Table I). There is a non- significant difference between the groups in the means of the serum TNF- $\alpha$ level (Table 1). The mean serum levels of TNF- $\alpha$ decreased to $95.3 \%$ (Group II), $73.8 \%$ (Group III) and 86\% (Group IV) of the serum level of Group I. 
Table II shows significant differences between treated groups (Group IV, V, VI, VII) in the means of the serum levels of EGFR $(F=3.844$, $\mathrm{p}=0.021$ ). Animals treated with simultaneous administration of an oral dosage of vitamin $\mathrm{D}$ and topical application of K-carrageenan (Group VII) showed a significantly lower serum level of EGFR compared with the corresponding level of Group I $(614.3 \pm 69.7 \mathrm{pg} / \mathrm{ml}$ versus $1118.5 \pm 91.8 \mathrm{pg} / \mathrm{ml}$, $\mathrm{p}=0.014)$, which accounts $45.1 \%$ decrease). Oral administration of vitamin D (Group V) and topical application of K-carrageenan (Group VI) produced a non-significant decrease of the EGFR serum levels in rats treated with topical application of DMBA by $8.9 \%$ and $13.6 \%$ of the serum level of EGFR of rats treated with DMBA alone (Group IV). A non-significant increase of serum levels of TNF- $\alpha$ were observed in animals treated with oral doses of vitamin D (Group V), topical application of K-carrageenan (Group VI), and both treatments (Group VII) by 26.8\%, 25.6\%, and 4.5\%, respectively compared with animals treated with DMBA alone (Group IV).

Figures 1 and 2 show the effects of different pharmacological interventions on the serum levels of EGFR and TNF- $\alpha$ in animals bearing tumors which induced by a topical application of DMBA in rats.

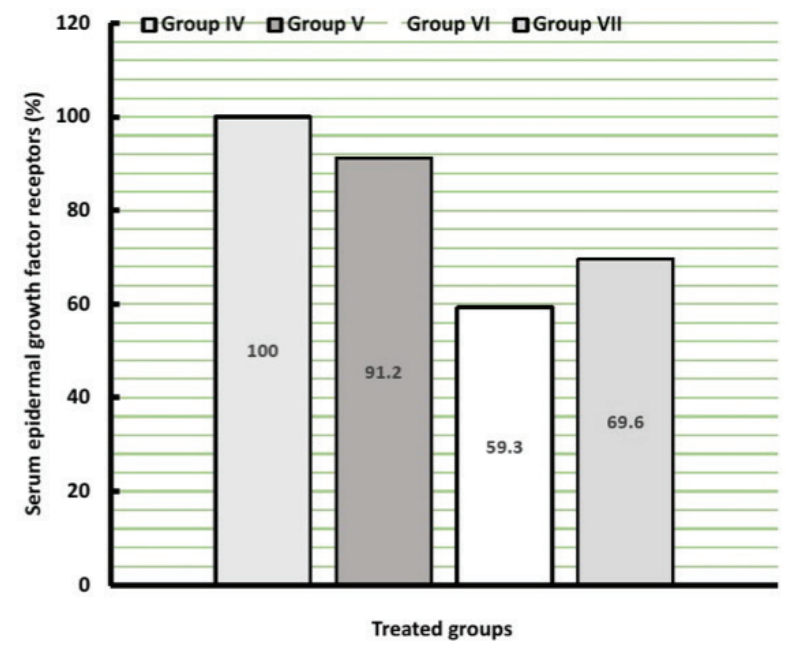

Figure 1 - Percentage changes in the serum levels of epidermal growth factor recptors in rats bearing tumors, treated with oral dosage of vitamin D (Group V), topical application of $\mathrm{k}$-carrageenan (Group VI), and simultaneous administration of oral vitamin D and topical k-carrageenan (Group VII) compared wih rats bearing tumors induced by DMBA (Group IV).

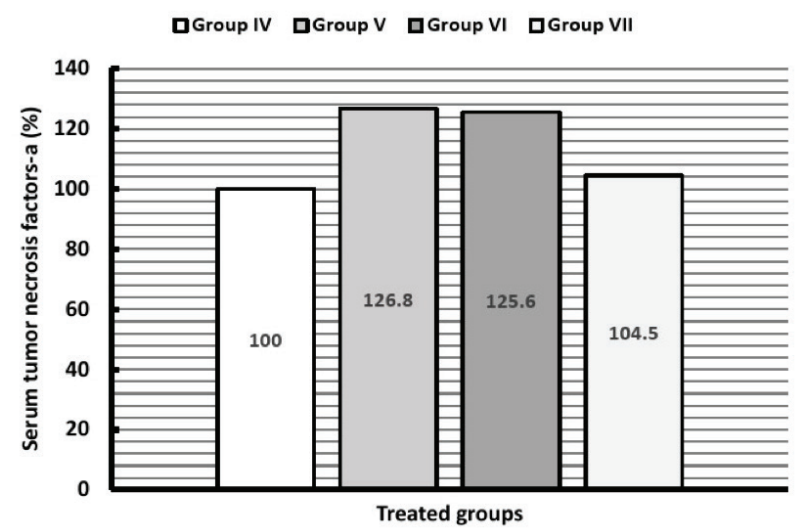

Figure 2 - Percentage changes in the serum levels of tumor necrosis factor- $\alpha$ in rats bearing tumors, treated with oral dosage of vitamin D (Group V), topical application of $\mathrm{k}$-carrageenan (Group VI), and simultaneous administration of oral vitamin D and topical k-carrageenan (Group VII) compared wih rats bearing tumors induced by DMBA (Group IV).

Table I - Baseline data of the effect of vitamin D, Carrageenan, combined vitamin $\mathrm{D}$ and carrageenan, and DMBA on the serum levels epidermal growth factor receptor (EGFR) and tumor necrosis factor (TNF)- $\alpha$ in rats.

\begin{tabular}{|ccc|}
\hline Treated groups & EGFR & TNF- $\alpha$ \\
\hline & $1118.5 \pm 91.8$ & $39.03 \pm 4.44$ \\
\hline Group I $(\mathrm{n}=7)$ & $(633.4-1349.4)$ & $(21.18-51.55)$ \\
\hline Group II $(\mathrm{n}=9)$ & $1072.3 \pm 21.3$ & $37.16 \pm 5.68$ \\
& $(1001.4-1199.4)$ & $(14.27-66.09)$ \\
\hline Group III $(\mathrm{n}=7)$ & $869.7 \pm 51.2$ & $28.82 \pm 6.79$ \\
& $(705.4-1059.4$ & $(2.46-51.54)$ \\
\hline Group IV (n010) & $882.4 \pm 45.6$ & $33.55 \pm 6.09$ \\
F-value & $(653.4-929.4)$ & $(2.46-57.9)$ \\
\hline p-value & 5.530 & 0.506 \\
\hline Comparison between Groups & 0.004 & 0.681 \\
\hline Group I versus Group II & 0.932 & 1.000 \\
Group I versus Group III & 0.025 & 1.000 \\
Group I versus Group IV & 0.020 & 1.000 \\
Group II versus Group III & 0.063 & 1.000 \\
Group II versus Group IV & 0.054 & 1.000 \\
Group III versus Group IV & 0.998 & 1.000 \\
\hline
\end{tabular}

The results are expressed as mean \pm SEM (range). F-value was calculated by using ANOVA with posthoc Boneferroni test to calculate the $p$-value of the differences between groups. Group I: acetone-treatment, Group II: Vitamin D-treatment, Group III: carrageenan-treatment, and Group IV: DMBA-treatment 
Table II - Effect of vitamin D, Carrageenan, combined vitamin $\mathrm{D}$ and carrageenan, on the serum levels epidermal growth factor receptor (EGFR) and tumor necrosis factor (TNF)- $\alpha$ in rats treated with DMBA.

\begin{tabular}{|ccc|}
\hline Treated groups & EGFR & TNF-a \\
\hline Group IV $(\mathrm{n}=10)$ & $882.4 \pm 45.6$ & $33.55 \pm 6.09$ \\
& $(653.4-929.4)$ & $(2.46-57.9)$ \\
\hline Group V $(\mathrm{n}=7)$ & $804.8 \pm 49.4$ & $42.53 \pm 7.47$ \\
& $641.4-929.4)$ & $(1.182-59.73)$ \\
\hline Group VI $(\mathrm{n}=7)$ & $762.8 \pm 71.7$ & $42.14 \pm 8.20$ \\
& $(523.4-1135)$ & $(1.18-65.18)$ \\
\hline Group VII $(\mathrm{n}=7)$ & $614.3 \pm 69.7$ & $35.05 \pm 10.48$ \\
\hline F-value & $(363.4-489.4)$ & $(1.55-74.27)$ \\
\hline p-value & 3.844 & 0.359 \\
\hline Comparison between Groups & 0.021 & 0.021 \\
\hline Group IV versus Group V & 1.000 & 1.000 \\
Group IV versus Group VI & 0.877 & 1.000 \\
Group IV versus Group VII & 0.014 & 1.000 \\
Group V versus Group VI & 1.000 & 1.000 \\
Group V versus Group VII & 0.220 & 1.000 \\
Group VI versus Group VII & 0.588 & 1.000 \\
\hline
\end{tabular}

The results are expressed as mean \pm SEM (range). F-value was calculated by using ANOVA with posthoc Boneferroni test to calculate the $p$-value of the differences between groups. Group IV: DMBA-treatment, Group V: Vitamin D followed DMBAtreatment, Group VI: carrageenan followed DMBA-treatment, and Group VII: Both vitamin D and carrageenan followed DMBA-treatment

\section{DISCUSSION}

The results of this study showed that DMBA as a carcinogenic substance induced significant changes in the serum EGFR and the therapeutic modalities in form of topical application of K-carrageenan and systemic oral administration of vitamin D produce significant changes in the EGFR in rats bearing tumors but not in control rats. A non-significant difference in the serum level of the TNF- $\alpha$ in rats bearing tumors and control is contradictory to the previous studies. A significantly higher salivary TNF- $\alpha$ was observed in patients with oral squamous cell carcinoma compared with healthy subjects [20]. Other studies found that exogenous TNF- $\alpha$ induces the transition of inflammation in the tumor stroma [21]. On the other side, Schiegnitz et al. [22] demonstrated that serum TNF- $\alpha$ level is not a useful associated or prognostic marker of oral squamous cell carcinoma patients as IL-6, IL-8, and soluble IL-2R. Conflicting results about the level of TNF- $\alpha$ relates to the methodology of each study. Topical application K-carrageenan or systemic oral administration of vitamin D produced an increment of TNF- $\alpha$ level in rats bearing tumor while concomitant administration of these agents does not produce considerable incremental. Carrageenan per se can induce inflammation and thereby increased the serum level TNF- $\alpha$ which explained our findings [23]. The explanation of systemic oral vitamin $\mathrm{D}$ produced an increment of TNF- $\alpha$ level is a little bit complicated. A significant weak inverse correlation between the serum level of TNF- $\alpha$ with the serum vitamin $\mathrm{D}$ was observed in patients with chronic periodontitis [24]. In breast cancer, the antiproliferative effect of vitamin $\mathrm{D}$ is enhanced by using TNF- $\alpha$, in addition calcitriol enhances the synthesis of TNF- $\alpha$ [25]. Therefore, the positive effect of vitamin $\mathrm{D}$ on the serum level of TNF- $\alpha$ in rats bearing tumors confirmed the other studies that showed vitamin D has an antiproliferative effect. Concomitant using of oral administration of vitamin D and a topical application of $\mathrm{K}$-carrageenan resulted in a nonconsiderable increment of TNF- $\alpha$ levels indicating that each substance acts in different signalling pathway resulting in a term of antagonism in the synthesis or generation of TNF- $\alpha$. Serum level of EGFR is significantly decreased in rats bearing tumor. Current studies demonstrated that the expression of EGFR in oral squamous cell carcinoma is less than other markers [26].

K-carrageenan significantly decreases the serum level EGFR in rat bearing tumor while vitamin $\mathrm{D}$ does not have this effect. As early as 1997, He et al [27] reported that the selenocarrageenan suppressed the proliferation of breast cancer cell by a mechanism related to the regulation of EGFR. Again, the level of EGFR is higher in rats treated with combined therapy of vitamin $\mathrm{D}$ and $\mathrm{k}$-carrageenan indicating an antagonism between these substances. It is 
important to emphasize herein that EGFR level tended to be decreased in oral cell carcinoma, and a further decrease by PEG-8000 indicates a good prognosis.

\section{CONCLUSION}

We conclude that both $\mathrm{K}$-carrageenan and vitamin $\mathrm{D}$ have antiproliferative effect against DMBA-inducing oralcancerbyincreasing thelevels of TNF- $\alpha$ and suppressing the signaling pathway of EGFR. Concomitant using K-carrageenan and vitamin $\mathrm{D}$ reduces the antiproliferative effect of each other.

Acknowledgement: The author express their appreciation to the Dean of the Faculty for supporting this study.

\section{Conflicts of interest: nil}

Funding: The College of Dentistry at the University of Baghdad

Author contribution: equally shared with this study

\section{REFERENCES}

1. Wright KD, Miller BS, El-Meanawy S, Tsaih SW, Banerjee A, Geurts AM, et al. The p52 isoform of SHC1 is a key driver of breast cancer initiation. Breast Cancer Res. 2019;21(1):74. doi:10.1186/s13058-019-1155-7

2. Alyoussef $A$, Taha M. Blocking Wnt as a therapeutic target in mice model of skin cancer. Arch Dermatol Res. 2019;311(8):595-605. doi:10.1007/ s00403-019-01939-4

3. Zingue S, Kamga Silihe K, Fouba Bourfane I, Boukar A, Tueche AB, Njuh AN, et al. Potential of regular consumption of Cameroonian Neem (Azadirachta indica L.) oil for prevention of the 7,12-dimethylbenz(a)anthraceneinduced breast cancer in high-fat/sucrose-fed Wistar rats. Evid Based Complement Alternat Med. 2019;2019:2031460. doi:10.1155/2019/2031460

4. Zeweil MM, Sadek KM, Taha NM, EI-Sayed Y, Menshawy S. Graviola attenuates DMBA-induced breast cancer possibly through augmenting apoptosis and antioxidant pathway and downregulating estrogen receptors. Environ Sci Pollut Res Int. 2019;26(15):15209-15217. doi:10.1007/ s11356-019-04920-w

5. Babukumar S, Vinothkumar V, Ramachandhiran D. Modulating effect of hesperetin on the molecular expression pattern of apoptotic and cell proliferative markers in 7,12-dimethylbenz(a)anthracene-induced oral carcinogenesis. Arch Physiol Biochem. 2019;1-10. doi:10.1080/13813455.2 018.1555600

6. Gopalakrishnan T, Ganapathy S, Veeran V, Namasivayam N. Preventive effect of D-carvone during DMBA induced mouse skin tumorigenesis by modulating xenobiotic metabolism and induction of apoptotic events. Biomed Pharmacother. 2019;111:178-187. doi:10.1016/j.biopha.2018.12.071
7. Moayedi Y, Greenberg SA, Jenkins BA, Marshall KL, Dimitrov LV, Nelson AM, et al. Camphor white oil induces tumor regression through cytotoxic T celldependent mechanisms. Mol Carcinog. 2019;58(5):722-34. doi:10.1002/ mc.22965

8. Dantas TS, Barros Silva PG, Lima Verde MEQ, Ribeiro Junior AL, Cunha MDPSS, Mota MRL, et al. Role of inflammatory markers in prognosis of oral squamous cell carcinoma. Asian Pac J Cancer Prev. 2019;20(12):3635-42. Published 2019 Dec 1. doi:10.31557/APJCP.2019.20.12.3635

9. Putra WE, Rifaï M. Immunomodulatory Activities of Sambucus javanica Extracts in DMBA-Exposed BALB/c Mouse. Adv Pharm Bull. 2019 Oct; 9(4):619-23. doi:10.15171/apb.2019.071

10. Lv XX, Zheng XY, Yu JJ, Ma HR, Hua C, Gao RT. EGFR enhances the stemness and progression of oral cancer through inhibiting autophagic degradation of SOX2. Cancer Med. 2020 Feb; 9(3):1131-40. doi:10.1002/ cam4.2772

11. HoesI C, Fröhlich T, Hundt JE, Kneitz H, Goebeler M, Wolf R, et al. The transmembrane protein LRIG2 increases tumor progression in skin carcinogenesis. Mol Oncol. 2019 Nov;13(11):2476-92. doi:10.1002/18780261.12579

12. Vigani B, Rossi S, Gentile M, Sandri G, Bonferoni MC, Cavalloro V, et al Development of a mucoadhesive and an in situ gelling formulation based on $\mathrm{k}$-carrageenan for application on oral mucosa and esophagus walls. II. Loading of a bioactive hydroalcoholic extract. Mar Drugs. 2019;17(3):153. Published 2019 Mar 5. doi:10.3390/md17030153

13. Sokolova EV, Menzorova NI, Davydova VN, Kuz'mich AS, Kravchenko AO, Mishchenko NP, et al. Effects of carrageenans on biological properties of echinochrome. Mar Drugs. 2018;16(11):419. Published 2018 Nov 1. doi:10.3390/md16110419

14. Liu Y, Qin Y, Bai R, Zhang X, Yuan L, Liu J. Preparation of pH-sensitive and antioxidant packaging films based on $\mathrm{k}$-carrageenan and mulberry polyphenolic extract. Int J Biol Macromol. 2019;134:993-1001. doi:10.1016/j. ijbiomac.2019.05.175

15. Souza RB, Frota AF, Silva J, Alves C, Neugebauer AZ, Pinteus S, et al. In vitro activities of kappa-carrageenan isolated from red marine alga Hypnea musciformis: Antimicrobial, anticancer and neuroprotective potential. Int J Biol Macromol. 2018;112:1248-1256. doi:10.1016/j.jibiomac.2018.02.029

16. Calvo GH, Cosenza VA, Sáenz DA, Navarro DA, Stortz CA, Céspedes MA, et al. Disaccharides obtained from carrageenans as potential antitumor agents. Sci Rep. 2019 Apr 30;9(1):6654. doi:10.1038/s41598-019-43238-y

17. Tan KW, Sampson A, Osa-Andrews B, Iram SH. Calcitriol and calcipotriol modulate transport activity of $\mathrm{ABC}$ transporters and exhibit selective cytotoxicity in MRP1-overexpressing cells. Drug Metab Dispos. 2018 Dec;46(12):1856-66. doi:10.1124/dmd.118.081612

18. Razak S, Afsar T, Almajwal A, Alam I, Jahan S. Growth inhibition and apoptosis in colorectal cancer cells induced by Vitamin D-Nanoemulsion (NVD): involvement of Wnt/ $\beta$-catenin and other signal transduction pathways. Cell Biosci. 2019 Feb 1;9:15. doi:10.1186/s13578-019-0277-z

19. Grant WB, Moukayed M. Vitamin D3 from ultraviolet-B exposure or oral intake in relation to cancer incidence and mortality. Curr Nutr Rep. 2019 Sep;8(3):203-11. doi:10.1007/s13668-019-0262-5

20. GD, Nandan SRK, Kulkarni PG. Salivary tumour necrosis factor- $\alpha$ as a biomarker in oral leukoplakia and oral squamous cell carcinoma. Asian Pac J Cancer Prev. 2019 Jul 1;20(7):2087-93. doi:10.31557/ APJCP.2019.20.7.2087 
21. Böhrnsen F, Holzenburg J, Godek F, Kauffmann P, Moser N, Schliephake H. Influence of tumour necrosis factor alpha on epithelial-mesenchymal transition of oral cancer cells in co-culture with mesenchymal stromal cells. Int J Oral Maxillofac Surg. 2020;49(2):157-165. doi:10.1016/j. ijom.2019.06.001

22. SchiegnitzE, Kämmerer PW, Schön H, Blatt S, Berres M, Sagheb K, et al Proinflammatory cytokines as serum biomarker in oral carcinoma-A prospective multi-biomarker approach. J Oral Pathol Med. 2018 Mar;47(3):268-74. doi:10.1111/jop.12670

23. Sur B, Kang S, Kim M, Oh S. Inhibition of carrageenan/kaolin-induced arthritis in rats and of inflammatory cytokine expressions in human IL-1 1 stimulated fibroblast-like synoviocytes by a benzylideneacetophenone derivative. Derivative. Inflammation. 2019;42(3):928-936. doi:10.1007/ s10753-018-0947-8

24. Wang Q, Zhou X, Jiang J, Zhang P, Xia S, Ding Y, et al. Relationship between serum 25-hydroxyvitamin D3 levels and severity of chronic periodontitis in type 2 diabetic patients: A cross-sectional study. J Periodontal Res. 2019;54(6):671-680. doi:10.1111/jre.12669
25. Martínez-Reza I, Díaz L, Barrera D, Segovia-Mendoza M, Pedraza-Sánchez S, Soca-Chafre G, et al. Calcitriol inhibits the proliferation of triple-negative breast cancer cells through a mechanism involving the proinflammatory cytokines IL-1ß and TNF- $\alpha$. J Immunol Res. 2019;2019:6384278. doi:10.1155/2019/6384278

26. Etemad-Moghadam S, Alaeddini M. Upregulation of ADAM10 in oral squamous cell carcinoma and its correlation with EGFR, neoangiogenesis and clinicopathologic factors. J Craniomaxillofac Surg. 2019 Oct;47(10):1583-8. doi:10.1016/j.jcms.2019.07.008

27. He G, Cheng C, Lu R. Studies on biological effects of kappaselenocarrageenan on human breast cancer cell line BCaP-37. Zhonghua Yu Fang Yi Xue Za Zhi. 1997 Mar;31(2):103-6.

\section{Marwan S.M. Al-Nimer}

(Corresponding address)

Professor of Clinical Pharmacology

Department of Pharmacology and Toxicology

College of Pharmacy

Hawler Medical University

Date submitted: 2020 Nov 02

Street No. 100, Erbil-Iraq

Accept submission: 2020 Mar 03 